\title{
Decreasing birth weight is associated with adverse metabolic profile and lower stature in childhood and adolescence
}

\author{
José Derraik*, Deborah Rowe, Wayne Cutfield, Paul Hofman \\ From 8th APPES Biennial Scientific Meeting \\ Darwin, Australia. 29 October - 1 November 2014
}

\section{Objective}

We aimed to evaluate the association of birth weight SDS (BWSDS) with insulin resistance, blood pressure, and auxology in children and adolescents born 2342 weeks of gestation.

\section{Methods}

We studied 143 singleton children and adolescents aged $9.3 \pm 3.3$ years (range $2.0-17.9$ years). Clinical assessments included auxology, insulin resistance measured by the HOMA2-IR, and blood pressure from sphygmomanometer measurements. Continuous associations were examined and stratified analyses carried out. For the latter, participants were divided into those of below-average birth weight (BBW, $<0$ SDS) and above-average birth weight (ABW, $\geq 0$ SDS).

\section{Results}

Irrespective of gestational age, lower BWSDS was associated with progressively increased insulin resistance $(\mathrm{p}<0.0001)$ and fasting insulin concentrations $(\mathrm{p}<0.0001)$. Decreasing BWSDS was associated with higher systolic $(\mathrm{p}=0.011)$ and diastolic $(\mathrm{p}=0.006)$ blood pressure. Lower BWSDS was also associated with decreasing stature $(\mathrm{p}<0.010)$. The BBW group was $\sim 40 \%$ more insulin resistant than ABW participants $(\mathrm{p}=0.004)$, with the former also displaying fasting insulin concentrations $37 \%$ higher $(\mathrm{p}=0.004)$. BBW participants were 0.34 SDS shorter than those of higher birth weight $(\mathrm{p}=0.002)$. On average, BBW participants failed to meet their genetic potential, tending to be shorter than their parents $(\mathrm{p}=0.065)$. As a result, when corrected for parents' heights, BBW participants were 0.6 SDS shorter than those born of higher birth

Liggins Institute, University of Auckland, New Zealand

weight ( $\mathrm{p}=0.001)$. Sub-group analyses on participants born appropriate-for-gestational-age $(\mathrm{n}=128)$ showed that associations of BWSDS with both insulin resistance and stature remained (although attenuated).

\section{Conclusion}

Decreasing BWSDS (even within the normal range) is associated with adverse metabolic profile and lower stature in children and adolescents.

Published: 28 April 2015

doi:10.1186/1687-9856-2015-S1-P110

Cite this article as: Derraik et al:: Decreasing birth weight is associated with adverse metabolic profile and lower stature in childhood and adolescence. International Journal of Pediatric Endocrinology 20152015 (Suppl 1):P110.

Submit your next manuscript to BioMed Central and take full advantage of:

- Convenient online submission

- Thorough peer review

- No space constraints or color figure charges

- Immediate publication on acceptance

- Inclusion in PubMed, CAS, Scopus and Google Scholar

- Research which is freely available for redistribution 